\title{
Investigating how teacher educators can foster delight in learning of preservice teachers
}

\author{
Naomi Thomas*1, Audrey Msimanga2, and Eunice Nyamupangedengu3 \\ 1, 2, 3 School of Education, University of the Witwatersrand, Johannesburg, South Africa
}

\begin{abstract}
Fostering preservice teachers' delight in learning life sciences through group discussion has recently become a focus of researchers and teacher educators globally. What do we learn? This is not a simple question to answer. In addition, how do we bring learning into our work as teacher educators? The reason for this is partly due to the characteristics of the goal and background of education, as well as the characteristics of students as individuals who are diverse in every way and constantly changing. Dialogic talk, which takes account of various concepts, facilitates logical comprehension in science, and lines with the curriculum in South Africa. The issue is that it is difficult to promote conversation, and can run counter to cultural norms. In South Africa, teacher educators have supported the need to foster students' creativity through the teacher education programme, however little is known about how teacher educators facilitate this daunting challenge. The purpose of the study was to explore how teacher educators prepare preservice teachers to model science talk in their lectures as well as investigate sociocultural factors of students' engagement with life science concepts as they craft arguments to support their claims or evidence in their given task. The study methodology was qualitative with an interpretive worldview. The design of the study was a case study of third-year life science preservice teachers. The participants were selected based on their willingness to participate in the purposive study. The communicative approach to science teaching was employed in the study. The result shows that teacher educators foster the delights of their preservice teachers to learn science concepts with scenarios as narratives video clips and power points slides. To foster delight in teaching life sciences in a multilingual setting, teacher educators need to be creative embracing all the complex dynamics of creating moment-bymoment challenging encounters. Hence teacher educators need to create an engaging and inclusive classroom environment.
\end{abstract}

Keywords: teacher education, learning, life sciences, preservice teachers, teacher educators.

\section{Introduction}

There was a significant shift in recent decades in the way students were taught science, which was viewed (Schmidt et al. 1997) as a fragmented set of messages presented through curriculums (European Commission 2015; NRC 2012). Students are asked to validate knowledge claims without following procedures or to perform activities that have weak 
conceptual links to underpinning scientific ideas (Roth and Garner, 2006). Among all students, Banilower et al. contend that very few engage deeply with science. (Krajcik et al 2014) aim to use the new instructional practice reforms to engage students in classroom activities to improve science instruction. Teachers must collaborate with their students in the process of learning and teaching to achieve this goal (Windschitl \& Stroupe, 2017). Design changes will be a key factor in the science classroom's social plane of instructional activities (NRC 2015). Hence teacher educators need to create opportunities in the classroom experiences of their students to reflect the current science education reforms with cognitive demanding activities afforded to learn science (Tekkumru-Kisa, Hiester, \& Kisa, 2017; Tekkumru-Kisa, Schunn, \& Stein, 2019). Opportunities to learn are determined by the task educators engage students within the classroom and how these tasks can foster the delight of preservice teachers to learn (Greeno and Gresalfi 2008; NRC, 2015). Although challenging, fostering delight in the teacher education science classroom is possible due to the diversity of student background being de Witt, Prost, Osborne, B., Archer, L., Dillon, J., Willis, B. and Wong, B. (2013). Several factors contribute to this difficulty, including (a) didactic teaching, which portrays students as unwilling bystanders whose job is to memorize expert claims (Lyons, 2006; Osborne \& Dillon, 2008); (b) a disconnect between official science curricula and student interests (Aikenhead, 1996); and (c) a lack of teacher familiarity with current scientific agendas, discoveries, and methodologies (Aikenhead,1996); ); and (c) a teacher's lack of knowledge of current scientific agendas, findings, and methodologies (Chubb, 2014). Learning content, purposes, and physical settings are changing (Duschl, 2008; Sadler, 2004); STEM subjects are being integrated (Scott, 2012); more links with practicing scientists are developing (Chubb, 2014); and virtual resources are becoming more common (Linn, 2014). solutions. Scientists are increasingly convinced that students must visualize, understand, implement, and value science in order to learn (Choi, Klein, \& Hershberger, 2015; Duschl, 2008; Hand, McDermott, \& Prain, 2016; Moje, 2007). The students should be exposed to these scientific practices, which are described by Peirce (1931-1958) as problems-solving processes that result in justified ideas about natural events. In addition to practical investigations, students can use visual, verbal, and mathematical models to understand how phenomena change. (Lemke, 2016; Duschl, 2008). Throughout the scientific process, students gain knowledge and skills and learn how to present their findings using diagrams, drawings, models, and verbal explanations (Ainsworth, Prain, and Tytler, 2011; Liu, 2011; Won, \& Treagust, 2014). Teachers and educators offer opportunities for students to learn through these platforms of encouragement. the tasks offered to pupils have an impact on their learning opportunities (Doyle 1983; Hiebert and Grouws 2007; Greeno and Gresalfi 2008; Stein et al. 1996). In a report published by the National Research Council (NRC) in 2015, it is noted that:

The types of tasks that students are asked to engage in will look different in a classroom aligned to the NGSS. For example, simply memorizing a science vocabulary list - such as the names of parts of a cell or reading a textbook selection and answering questions at the end of the chapter that requires students to restate or repeat portions of the text-is not consistent with the vision for learning in the Framework and the NGSS. Instead, students could be asked to explain how the function of a particular part of the cell fulfills the organism's needs and use evidence to support that explanation (p. 34). 


\section{4th International conference on Advanced Research in Education, Teaching \& Learning}

This example (Tekkumru-Kisa et al., 2015) illustrates that diverse science activities require students to think at different levels and types of levels, versus a more or less similar level of interaction with scientific concepts and methodology in all assignments. Learning through exposure to the subject matter is not the best way to recognize learning potential (Hiebert and Grouws 2007). The activity-based learning approach emphasizes learning and provides students opportunities to see what they might be exposed to (Doyle, 1983; Stein, Grover, \& Henningsen, 1996; Tekkumru-Kisa, Schunn, \& Stein, 2015). The activities may involve students in scientific ideas, while others require them to engage with and develop a deeper concept. Therefore, different types of student thinking are required for different tasks (Stein, Smith, Henningsen, \& Silver, 2000; Tekkumru-Kisa et al., 2015). High-quality, comprehensive activities provided rich learning opportunities for students to participate in and make sense of content and discipline as considered in recent educational reforms (Tekkumru-Kisa et al., 2015; Tekkumru-Kisa et al., 2020. There is a problem, however, with the limited access students have to such high-level activities in many science classes (Banilower et al., 2013; Weiss, Pasley, Smith, Banilower, \& Heck, 2003). To address this problem, teachers are being encouraged to build repertoires of activities that engage students in deeper and meaningful learning experiences (e.g., Kang, Windschitl, Stroupe, \& Thompson, 2016; Tekkumru-Kisa et al., 2017; Tekkumru- Case, Stein, \& Coker, 2018). We argue that the types of tasks that teachers assign to students provide a vantage point through which to understand how pupils are positioned to learn in science classrooms. In the classroom, generating and selecting educational tasks is a collaborative effort between the teacher and students. (Doyle 1983). These tasks constitute the system of activities that produce social encounters for learning.

Teacher preparation programs provide one way for pre-service teachers to acquire skills and knowledge of practice that provide solid learning opportunities for all students in science classes (Windschitl \& Stroupe, 2017; Windschitl, Thompson, Braaten, \& Stroupe, 2012). Indeed, curriculum design is emphasized as a key teaching practice that can support students' core competencies in higher education. (Ball \& Forzani, 2009, 2011; Ball, Sleep, Boerst, \& Bass, 2009) In selecting such high-profile practices, teaching pedagogy (2018) emphasizes teacher educators to design courses that provide opportunities for research and student discovery, and include opportunities for students to practice and learn basic concepts and skills. Therefore, to combat the lack of high-quality skills in science classes, teacher preparation programs can play a very important role, especially as they support pre-service teachers learning to create solid lessons designed for critical thinking. To inform future efforts to support pre-service teachers by developing critical thinking, in this exploratory study we want to understand what kind of interaction fosters delight for pre-service teachers learning life sciences. (Doyle, 1988; Hiebert \& Grouws, 2007; Stein et al., 2000; TekkumruKisa, Schunn, Stein, \& Reynolds, 2019), explored the need for an understanding of preselected scientific activities. In this article we define the search for understanding as to the level and type of thinking needed by students to successfully engage in scientific activities; and active participants in meaning negotiation (Stein et al., 1996; Tekkumru-Kisa et al., 2015). Hence the role of teacher educators to deliberately create moments of delight and balance of academic rigor in their teaching process challenges the transmissive mode of instruction and hence key collaborative knowledge sharing (Banilower et al. 2018). One of the questions that guided the study was: 
How do biology teacher educators facilitate productive conversation in their classrooms?

\section{Theoretical perspective}

Learning, as seen from the sociocultural perspective involves the ever-changing participation in a community of practice (Lave \& Wenger, 1991), a framework that emphasizes people's social resources for learning. In light of this, we investigated how teacher educators practice in a teacher education programme as they create opportunities for preservice teachers to learn science concepts in a multilingual lecture setting. Through the lens of social construction, learning takes place by adding, subtracting, re-arranging them, or in some other way the renaming of beliefs, processes, or practices. PreserviBy modifying their previous experiences, preservice teachers refine existing ideas and make new ones (Anderson et al. 2003; Palincsar 1998). The influence of change is also reflected in students' engagements, as they can apply new concepts to differentiate science phenomena (Lave and Wenger, 1991). Learning usually occurs through continuous participation in subsequent experiences (Gresalfi et al. 2009), but participation does not equal self-study. The basis for learning is participation, but learning is not limited to participation in the present; it shapes participation in the future as well" (Moje and Lewis 2007, p. 16). The dialogue between teachers and students is crucial to the development of learning in science. To promote effective instruction in science, teachers, and students should actively participate in the classroom discourse of building, sharing, and refining knowledge (Lemke 1990). Hence the crucial role of teacher educators in fostering realistic learning experiences and promotes classroom discussion. (National Academy of Engineering and National Research Council 2014; National Research Council 2012). Preservice teachers should be able to understand and use the specialized language of science in speaking, writing, and reasoning during class discussions (Lemke 1990, p. 167). Teachers must abandon traditional teaching techniques, encourage constructive debates, and promote participation in the construction of knowledge by all students. Teachers may use a range of strategies and discussion steps to facilitate constructive conversations. (Michaels \& O'Connor 2012, p. 7) Teacher discourse moves are proactive teacher actions that foster student engagement, explanation, and reasoning. Peers facilitate the creation of meaning as well. As peers discuss socially with their understanding of the social situation, they establish categories, classify, while defining new ideas, they change their understanding of concepts (Kapur and Bielaczyc 2012). Similarly, peer communication can act as a barrier to learning since it calls for discussions of a variety of knowledge sources as well as access to ideas, objects, and perspectives (Engle et al. 2014). Interaction mode, which extends beyond the presentation of confusing information "The study provides various types of statements, questions, observations, modeling, gestures, and emotions (Tuyay et al. 1995, p. 76). Learning opportunities occur when students are provided with help explaining the tasks, experiences, and knowledge, and it occurs when participants interact with new information connected to their previous knowledge. We see the opportunity for learning through social interactions in the classroom, according to the sociocultural perspective of learning. In the process of internalizing the ideas developed through the process of social interactions in the process of teaching encounters, preservice teachers can develop their ideas and refine their prior understandings 


\section{Methodology/Case Selection}

The study adopted a qualitative approach and an interpretive paradigm to explore how teacher educators foster delight in teacher education. A case study was employed to understand the complex nature of interaction in the process of teaching and learning in a natural setting (Yin, 2003). The participants were purposively invited to participate in the study for the purpose that they can give the relevant data due to the experience they acquire over time interacting with preservice teachers as they model their practice in a teacher education classroom.

\section{Setting and participants}

The study was conducted at a public university in South Africa. Teachers educators are responsible for teaching both disciplinary content and pedagogy to preservice teachers through the concurrent model Zuzovsky \& Donita-Schmidt (2017; Nyamupangedengu, 2016).

The complementary model incorporates and teaches both disciplinary content and Simultaneous Teaching methods (Musset 2010). The goal of this model is to allow the integration of the many components of a teacher education programme.

\section{Data generation process}

In the qualitative study to generate data, I observed teacher educators in their lecture which took about an hour, and interviewed them to gain an in-depth understanding of the phenomenon of study. Non-participant observer, the researcher watched all four teacher teachers in two cycles. The first cycle took place in 2017 in the fourth block of the study session and 2018 in the first and second block of the study session. About an hour's worth of lessons were recorded at each lecture. In total, fifteen lessons were examined for the study. Describe and discuss a phenomenon when doing an interview, according to Cohen, Manion, and Marisson (2014). The interview allowed the participant to discuss how they engage with preservice teachers in their lectures to create the moment-by-moment learning encounter in the social plane of the science classroom. Two questions used to generate data from the interview are: What would count as evidence that the lecture was successful for the topic of discussion? What are the ideas of teaching and/or learning entrenched in your Slide designs? An excerpt of one of the educators' interviews is shown below.

The session of the interview took fifteen to twenty minutes and they were audio-recorded as the source of data and transcribed verbatim. From the teacher educations perspectives on their practice, they all believe in interactive lectures however there engage their preservice teachers differently in content delivery to foster delight for learning of science concepts.

\section{Data analysis}

To familiarize myself with data generated I read through the teaching transcript to understand how teacher educators create opportunities for preservice teachers to learn. 
After getting myself acquainted with the data. Data were coded identifying opportunities created by teacher educators in the course of their teaching of different topics of life sciences in the science classroom. The coding was employed to help me sort out the details of opportunities created to learn in the science classroom. From the codes generated from my first transcript analysis, I grouped different codes into categories of seven broad themes. From the seven categories, I proceed to analyze both deductively and inductively three teaching transcripts from different teacher educators to see what might emerge. The deductive analysis of both the teaching transcript and the interviews was informed by the theoretical perspective of the study. Below is an example of a coded teaching transcript.

1 There is a worksheet that we will do in class and submit at the end of the lecture. assigns a task to the class $\mathbf{O T L}$ ) the task is to assess the students' prior knowledge

2 You will need to do some research and look at how the population increase of human beings affects the environment and debates around what is meant by 'over-population (TE instructs preservice teachers to research how population increase affects the environment and discuss issues of overpopulation) $\mathrm{OTL}$

3 what is ecology and what is population ecology? TE asks the class a question to review the students' prior understanding of ecology in general. OTL

4 Why do we study these two? TE asks the class a follow-up question OTL

5 What is ecology and what is population ecology...? TE ask a question for preservice teachers to differentiate between ecology and population ecology OTL

6 How do population ecology and ecology differ? What is the purpose of studying them? Following up with the OTL to the class, the TE asks some questions

7 Any other contributions? (TE ask for additional rejoinder for clarity $\mathbf{O T L}$

8 How do you differentiate it from community ecology? TE ask for an additional response for clarity $\mathrm{OTL}$

The focus of the study is to investigate how teacher educators create opportunities for preservice teachers to learn biology with a diverse population of students in a multilingual lecture setting. The initial inductive coding of date yielded sixty-two codes which were later refined into seven themes. However, I pulled out three of the theme for this paper in line with the topic of fostering delight in creating opportunities to learn by teacher educators in a whole-class discussion. The three themes are provided below.

- Teacher educators engage the class with video clips to introduce a concept.

- Teacher educators introduce concepts by creating scenarios as a form of visual communication.

- Teacher educators employ PowerPoint slides to illustrate a concept. 
The use of video clips to foster delight in learning.

62 Okay, welcome to the Anthropocene is a video that I downloaded to bring us before what is happening. We are talking here about the environment, development, and education but one thing is portrayed is that development can be explained in two levels in the 17 and 18 centuries and then we had what we call industrial development. And that industrial development came along with economic development. So somewhere in this era, there is something we call the colony as we talk about development we are supposed to be talking about industrial but we don't just do industrial we do industrial to further economic development. So we have this obvious development that has helped to transform the world to where it is today and do you remember that the geological time scale has all those epochs $O T L$

Introducing concepts by creating scenarios as a form of visual communication fosters delight to learn.

And how to deal with it. Inequitable distribution of resources you go to one part of the town you are walking under trees and you go to another part of the town only one street even bigger vehicle cannot move. There are no trees and the houses are the cheapest and you have the largest concentration of people in that place. If you look just across the street you will see 18-20 roofed houses and is probably just the husband and the wife with grown children they only have one or two. And what does that mean in terms of resources? $T E$ introduces concepts creating a scenario to engage the mind of the class OTL

The use of PowerPoint slides to illustrate a concept fosters the delight of preservice teachers to learn.

37 That is why I said at the beginning of the lecture that the range is very specific...very important in population ecology. So, it is the number of individuals per unit area and demographers study the statistics of populations $T E$ uses slides in explaining the specificity of range in population ecology and defines it as the number of individuals per unit area. OTL 


\section{Results and discussion}

The themes above in this case study provide evidence of engaging with preservice teachers in a large social plane to interact collaborate and foster delight in the course of teaching and learning encounters. Research establishes that science curriculum that incorporates these practices are effective in understanding the development of scientific knowledge, the process of scientific research, and Increases cognitive abilities in students (NRC 2012)

Jonah designs his slides in a way that engages his students with the topic of the discussion, thereby facilitating class interaction. Consequently, this allows students to contribute their ideas to classroom discussions, allowing them to become more involved in the content delivery. As Mr. Jonah engages preservice teachers in his lectures, his slides are designed to provide opportunities for students to participate, and thus, less text was used to allow for discussion and ideas to be solicited from the scholars.

Dr. Charles emphasizes the importance of his students' previous knowledge of life science topics before his lectures. Therefore, he has an interest in how students acquire new science concepts (Biggs and Moore, 1993). Consequently, he provides curriculum materials that engage his students' interests, thereby motivating them to learn.

When students demonstrate an understanding of the complexity of topics taught in lectures, and the complexity of topics is achieved by the end of the first year, then the educator can call her lectures successful. Student response to Ms. Rose's discussion, solving science problems, or explanation of the concept of discussion among preservice teachers with questions rather than the transmission of facts. The process of mediation is in line with the social-cultural theory employed in this study (Vygotsky, 1978).

Dr. Lydia analyzes classroom interactions concerning the teaching and learning of science, specifically how science teachers and students interact; how talk helps students understand science; what speaking reveals about students' reasoning; and what the use of language and silence means for the learning process.

Teacher educators prepare for the lectures differently to foster the delight of their preservice teacher to learn science concepts as provided by the results above. My argument is that the main ingredient is some kind of cohesion that comes from sharing in the same community space. When teacher educators design their lesson delivery materials with the focus of engaging students to learn, we create the conditions in which our hearts are stirred and their minds are shaped. The purpose of higher education is to foster individual and collective expressions of knowledge, knowledge and imagination in the purest form possible. We ask each other and ask ourselves how we know the world and how we can live happily, courageously, and with a commitment to learning what content we are taught. Social interaction is crucial to the process of learning, as it provides a setting where the opportunities for learning science are formed (Wright, 2011; Cook and Hennessy, 2018) 
Morton (2012) Reiser, Fumagalli, Novak, \& Shelton (2016) argued that three norms govern the classroom community's engagement in knowledge building, involves how participants engage with the science ideas and refine their understanding over time is relevant to their learning of science. Hence the use of scenarios to engage preservice teachers in large lecture settings fosters delight in the grasp of science concepts. Videos demonstrate complex situations in a way that is difficult to convey orally, and that can, in any case, be more vividly and powerfully presented by an actual participant than by a teacher educator observing the classroom activity at a distance. Additionally to Mitchell et al. (2010), Newton and Sorensen (2010) discussed how videos can be used as examples of good practice and as a means for students to share ideas. It is again evident how well video facilitates instructional activities because it can capture classroom encounters in the 'real world' (Schwartz, Hartman, 2007, p. 340). Ausubel's research has identified the importance of advanced organizers (AOs) for quicker and more effective learning in biology classrooms (Ausubel, 1978/). Ausubel (1968/2012) posited that learning in a meaningful way is only possible if new information is relevant to previous understanding. The use of these ideas supports the call for increasing visual literacy in biology (Arneson \& Offerdahl, 2018). PowerPoint slides create a structure to the instructional episode, with each slide serving as a micro AO within its larger course (Ausubel, 1978).

\section{Conclusion/recommendation}

Analysis of teaching reveals the themes of how teacher educators foster the delight of their preservice teacher as they engage them to learn science concepts with scenarios as narratives, video clips, and power points slides. The essence of content delivery with scenarios as narratives is to engage the minds of preservice teachers providing a platform for discussions and interactions. Also, the use of video clips provides a platform in a science lecture setting for preservice teachers to muse over the topic of discussion in the lecture. Teacher educators' use of power points slides is the ability to move seamlessly between visual representations of the physical and natural world is a crucial skill for scientists (Arneson \& Offerdahl, 2018). Using visualizations provides models for natural phenomena that are difficult to observe unaided (Tibell \& Rundgren, 2010) as well as provides a way to visually communicate complex scientific information. Biology involves much more use of visualizations than other disciplines to convey the complex interactions of biological systems on a wide scale (Tibell $\&$ Rundgren, 2010). This directly affecting classroom instruction, this has a significant impact. Students may be expected to interpret, decode, and interpret representations of phenomena represented by visuals, in addition to the use of visuals as a means of conveying information. Hence teacher educators need to foster delight in teaching life sciences in a multilingual setting, through modeling creative creating moment-by-moment challenging encounters in their lecture setting. And also need to create an engaging and inclusive classroom environment.

\section{Acknowledgment}

This paper is an output of funding support I received from the Faculty of Humanities as a Teaching Assistant at the University of the Witwatersrand, Johannesburg South Africa. 


\section{ORCID}

Naomi Thomas ID https://orcid.org/0000-0002-6744-7005

\section{References}

Aikenhead, G. S. (1996). Science education: Border crossing into the subculture of science.

Arneson, J. B., \& Offerdahl, E. G. (2018). Visual literacy in bloom: Using Bloom's taxonomy to support visual learning skills. CBE_Life Sciences Education, 17(1), $\operatorname{ar} 7$.

Ausubel, D. P. (2012). The acquisition and retention of knowledge: A cognitive view. Springer Science \& Business Media

Ausubel, D. P. (1978). In defense of advance organizers. A reply to critics. Review of Educational Research, 48, 251-257.

Banilower, E. R., Smith, P. S., Weiss, I. R., Malzahn, K. A., Campbell, K. M., \& Weis, A. M. (2013). Report of the 2012 national survey of science and mathematics education. Chapel Hill, NC: Horizon Research, Inc.

Biggs, J., and P. Moore. "Conceptions of learning and teaching." The process of learning (1993): 20-26.

Cian, H., \& Cook, M. (2018). Secondary science student teachers use verbal discourse to communicate scientific ideas in their field placement classrooms. Research in Science Education, 1-28.

Chubb, I. (2014). Australia needs a strategy. Science, 345(6200), 985. doi:10.1126/science. 1259741

Choi, A., Klein, V., \& Hershberger, S. (2015). Success, difficulty, and instructional strategy to enact an argument-based inquiry approach: experiences of elementary teachers. International Journal of Science and Mathematics Education, 13(5), 991-1011.

Cohen, L., Manion, L., \& Morrison, K. (2014). Research methods in education. Routledge.

De Witt, J., Osborne, J., Archer, L., Dillon, J., Willis, B., \& Wong, B. (2013). Young children's aspirations in science: The unequivocal, the uncertain, and the unthinkable. International Journal of Science Education, 35(6), 1037-1063. 
Duschl, R. (2008). Science education in three-part harmony: Balancing conceptual, epistemic, and social learning goals. Review of research in education, 32(1), 268291.

Engle, R. A., Langer-Osuna, J. M., \& McKinney de Royston, M. (2014). Toward a model of influence in persuasive discussions: Negotiating quality, authority, privilege, and access within a student-led argument. Journal of the Learning Sciences, 23(2), 245268.

Garner, P. W., Bolt, E., \& Roth, A. N. (2019). Emotion-focused curricula models and expressions of and talk about emotions between teachers and young children. Journal of Research in Childhood Education, 33(2), 180-193.

Greeno, J. G., \& Gresalfi, M. S. (2008). Opportunities to learn in practice and identity.

Hand, B., McDermott, M., \& Prain, V. (Eds.). (2016). Using multimodal representations to support learning in the science classroom. Switzerland: Springer International Publishing.

Kang, H., Windschitl, M., Stroupe, D., \& Thompson, J. (2016). Designing, launching, and implementing high-quality learning opportunities for students that advance scientific thinking. Journal of Research in Science Teaching, 53(9), 1316-1340.

Kapur, M., \& Bielaczyc, K. (2012). Designing for productive failure. Journal of the Learning Sciences, 21(1), 45-83.

Krajcik, J., Codere, S., Dahsah, C., Bayer, R., \& Mun, K. (2014). Planning instruction to meet the intent of the next generation science standards. Journal of Science Teacher Education, 25(2),

157-175. doi:10.1007/s10972-014-9383-2

Lemke, J. L. (2016). Demonstrating the value of informal learning. Retrieved from http://www.

jaylemke.com/

Linn, M., Davis, E., \& Bell, P. (2013). Internet environments for science education.Oxon: Routledge.

Lyons, T. (2006). Different countries, same science classes: Students' experiences of school science in their own words. International journal of science education, 28(6), 591613.

Mitchell, N., B. Marsh, A. J. Hobson, and P. Sorensen. 2010. "Bringing Theory to Life." Teacher Development 14 (1): 15-27. 
Moje, E. B. (2007). Developing socially just subject-matter instruction: A review of the literature on disciplinary literacy. In N. L. Parker (Ed.), Review of education research (pp. 1-44).

Washington, DC: American Educational Research Association

Morton, J. (2012). Communities of practice in higher education: A challenge from the discipline of architecture. Linguistics and Education, 23(1), 100-111.

National Research Council. (2012). A framework for K-12 science education: Practices, crosscutting concepts, and core ideas. Washington, DC: The National Academies Press.

National Research Council. (2015). Guide to implementing the next generation science standards. Committee on guidance on implementing the next-generation science standards. Board on science education, division of behavioral and social sciences and education. Washington, DC: The National Academies Press.

Newton, L. R., and P. D. Sorensen. 2010. “Science Teacher Development Through Constructive Engagement with Digital Video: Some Experiences from the Field." Paper presented at the International Seminar, Professional Reflections, National Science Learning Centre, York, February.

Osborne, J., \& Dillon, J. (2008). Science education in Europe: Critical reflections (Vol. 13). London: The Nuffield Foundation

Peirce, C. S. (1931-58). Collected papers of Charles Sanders Peirce. 8 volumes. (Eds. CharlesHartshorne, Paul Weiss \& Arthur W Burks, Vols 1-6), (Ed., Arthur W. Burks, vols 7-8). Cambridge, MA: Harvard University Press.

Reiser, B. J., Fumagalli, M., Novak, M., \& Shelton, T. (2016). Using storylines to design or adapt curriculum and instruction to make it three-dimensional. Paper presented at the NSTA National Conference On Science Education, Nashville, TN.

Schmidt, W., McKnight, C., \& Raizen, S. (1997). A splintered vision: An investigation of U.S. mathematics and science education. Dordrecht: Kluwer

Teaching Works. (2018). High leverage teaching practices. Retrieved from http://www.teachingworks.org/work-of-teaching/high-leverage-practices

Tekkumru-Kisa, M., Stein, M. K., \& Schunn, C. (2015). A framework for analyzing cognitive demand and content-practices integration: Task analysis guide in science. Journal of Research in Science Teaching, 52(5), 659-685.

Tekkumru-Kisa, M., Schunn, C., \& Coker, R. (2017). Promoting teachers' learning to select cognitively demanding science tasks. In Paper presented at the meeting of the European science education research association (ESERA). Dublin: Ireland. 
Tekkumru-Kisa, M., Schunn, C., Stein, M. K., \& Reynolds, B. (2019). Change in thinking demands for students across the phases of a science task: An exploratory study. Research in Science Education, 49(3), 859-883.

Tekkumru-Kisa, M., Schunn, C., Stein, M. K., \& Reynolds, B. (2019). Change in thinking demands for students across the phases of a science task: An exploratory study. Research in Science Education, 49(3), 859-883. DOI: 10.1007/s11165-017-9645-Z

Tekkumru-Kisa, M., Hiester, H., \& Kisa, Z. (2017, April). Nature of science tasks as a lens to understand students' opportunities to learn. Paper presented at Annual Meeting of the American Educational Research Association, American Educational Research Association (AERA), San Antonio, TX.

Tekkumru-Kisa, M., Stein, M. K., \& Coker, R. (2018). Teachers' learning to facilitate highlevel student thinking: Impact of video-based professional development. Journal of Research in Science Teaching, 55(4), 479-502.

Tibell, L. A. E., \& Rundgren, C. J. (2010). Educational challenges of molecular life science: Characteristics and implications for education and research. CBE-Life Sciences Education, 9, 25-33.

Windschitl, M., Thompson, J., Braaten, M., \& Stroupe, D. (2012). Proposing a core set of instructional practices and tools for teachers of science. Science Education, 96(5), 878-903. doi:10.1002/ sec.v96.5

Windschitl, M. A., \& Stroupe, D. (2017). The three-story challenge: Implications of the next generation science standards for teacher preparation. Journal of Teacher Education, 68(3), 251-261. doi:10.1177/0022487117696278

Wright, G. B. (2011). Student-centered learning in higher education. International Journal of Teaching and Learning in Higher Education, 23(1), 92-97. 